\title{
ОЦІНЮВАННЯ ПОТРЕБИ У ФАХІВЦЯХ В ОХОРОНІ ЗДОРОВ'Я ТА ЇХ ПІДГОТОВКИ В СИСТЕМІ ПІСЛЯДИПЛОМНОї ОСвІТИ \\ (Перше повідомлення)
}

\author{
Ю. В. Вороненко, О. П. Мінцер \\ Національна медична академія післядипломної освіти імені П. Л. Шупика
}

\begin{abstract}
Представлено основні принципи оцінювання кадрових ресурсів охорони здоров'я, можливості їх прогнозування. Проаналізовано методологічні труднощі обґрунтованого оцінювання підготовки кадрів. Ці труднощі розглянуто 3 позицій потреби населення в медичних послугах і попиту на них.
\end{abstract}

Ключові слова: кадрові ресурси охорони здоров'я, інформаційні технології, методи розрахунку потреби в кадрах, система охорони здоров'я, якість надання медичних послуг.

\section{ОЦЕНКА ПОТРЕБНОСТИ В СПЕЦИАЛИСТАХ В ЗДРАВООХРАНЕНИИ И ИХ ПОДГОТОВКИ В СИСТЕМЕ ПОСЛЕДИПЛОМНОГО ОБРАЗОВАНИЯ (Первое сообщение)}

\author{
Ю. В. Вороненко, О. П. Минцер \\ Национальная медицинская академия последипломного образования \\ имени П. Л. Шупика
}

\begin{abstract}
Представлены основные принципы оценки кадровых ресурсов здравоохранения, возможности их прогнозирования. Проанализированы методологические трудности обоснованной оценки подготовки кадров. Эти трудности рассмотрены с позиций потребности населения в медицинских услугах и спроса на них.
\end{abstract}

Ключевые слова: кадровые ресурсы здравоохранения, информационные технологии, методы расчета потребности в кадрах, система здравоохранения, качество оказания медицинских услуг.

\section{ASSESSMENT THE NEED FOR SPECIALISTS IN HEALTH CARE AND THEIR TRAINING IN THE POSTGRADUATE EDUCATION SYSTEM} (First post)

\author{
Yu. V. Voronenko, O. P. Mintser \\ National Medical Academy of Postgraduate Education by P. L. Shupyk

\begin{abstract}
The basic principles for evaluating staff resources of health care, the possibility of their forecasting are presented. Analyzed the methodological difficulties informed assessment training. These difficulties are discussed from the standpoint of the needs of the population for health services and the demand for them.
\end{abstract}

Key words: staff resources of health care, information technology, methods for calculating staffing requirements, the health care system, the quality of medical services.

Від авторів. Передбачається висвітлити матеріал у трьох статтях - перша призначена для формулювання проблеми, друга - обгрунтування власної методики розрахунку кадрових ресурсів охорони здоров'я (КРОЗ), і нарештті, третя - представлення аналітичних даних про можливість застосування методики.
Вступ. Обгрунтувати та спрогнозувати потребу в кадрових ресурсах галузі охорони здоров'я складно в будь-якій соціально-економічній і політичній ситуації. Проте, очевидно, що таке оцінювання необхідне та корисне, оскільки може допомогти попередити та скорегувати ризики виникнення кадрового дисбалансу (дефіциту, надлишку, нераціонального розподілу

(C) Ю. В. Вороненко, О. П. Мінщер 
кадрів), що обмежує доступність, ефективність та якість діяльності служб охорони здоров'я. Збільшується визнання важливості адекватного розрахунку потенційних ресурсів системи, щоби домогтися поліпшення доступу до них. У результаті ця проблема набула стратегічного значення та стала ключовою в цілому ряді нарад і оцінок ВООЗ.

Вочевидь, потреби в кадрових ресурсах повинні виражатися не тільки в загальних цифрах - критично важливими змінними $€$ такі аспекти робочого середовища, як розподіл (професійно-кваліфікаційна структура кадрів) і організація праці, види компетентності, умови праці, цільові показники продуктивності та якості. Важливо підкреслити, що хоча необхідність кількісних моделей та інструментів очевидна, проте вони можуть систематично застосовуватися тільки тоді, коли позитивно виражені соціальні та політичні позиції доступу до медичної допомоги та ії надання [1].

Зауважимо, що в жодній із країн світу не вдається вирішити проблему КРОЗ таким чином, щоб можна було назвати це зразком "передової практики", хоча деякі країни й докладають серйозних зусиль. Переважна більшість країн навіть в СС поки що не розпочинала зазначений процес. Більш детальну інформацію про дані й еталони для порівняння, необхідну для налагодження ефективно функціонуючої системи інформації з КРО3, можна знайти в World Health Organization (2010) Report of the first meeting of the Health [2].

Важливо підкреслити, що досвід таких країн, як Велика Британія, Бельгія, Ірландія, Іспанія та інших, котрі вкладали кошти та інші ресурси в оцінювання потреб у КРОЗ, переконливо демонструє важливість формалізації проблеми та створення відповідної інформаційної бази, щоздатна забезпечити достовірні, надійні та сучасні дані для моніторингу кадрових ресурсів у галузі охорониздоров'я й, відповідно, в підготовці кадрів. Без надійних даних оцінювання потреби в освіті перетворюється на ворожіння [3].

Оскільки в прийнятті рішень про майбутні КРОЗ беруть участь організації з різних секторів (освіта, охорона здоров'я, фінанси, планування, професійні організації, роботодавці, громади), конфліктів уникнути все одно неможливо. Тому завдання полягає в досягненні взаємоприйнятних домовленостей на глобальному та територіальних рівнях.

Мета дослідження: обгрунтувати концептуальну основу розрахунку необхідної кількості фахівців у кожному з напрямів системи охорони здоров'я.

Ще одним важливим завданням цього дослідження було прийняття як всеосяжного підходу до оціню- вання потреб, так і підходу, при якому потреби оцінюються за окремими професіями. Вважалось, що основоположною проблемою повинні стати обсяг, форма та структура підготовки фахівців, оцінювання відносного значення інтернатури, клінічної ординатури, резидентури, спеціалізації. Нарешті, вважалося вкрай важливим оцінювання еволюції інформаційних технологій і їх вплив на сектор охорони здоров'я.

Методи дослідження: аналітико-порівняльний, таксономії, експертних оцінок.

Результати та їх об́говорення. Вибір стратегії оцінювання майбутніх кадрових ресурсів охорони здоров'я є ціннісно-орієнтованим і залежить, на жаль, від того, які результати для здоров'я та які цілі медичного обслуговування заплановано керівниками вищої ланки. Протягом багатьох років міжнародними організаціями, так само як і окремими країнами, були запропоновані й випробувані різноманітні моделі, підходи та набори інструментів для оцінювання потреб у кадрових ресурсах. Зазвичай аналіз стану справ із кадровими ресурсами для визначення майбутніх потреб у персоналі будується на таких змінних, як прогнозовані зміни чисельності, структури i щільності проживання населення, технологічні та соціальні зміни, динаміка поширеності хвороб, професійно-кваліфікаційна структура, обсяги та якість виконання професійних функцій фахівцями на індивідуальному рівні, економіка та політика охорони здоров'я.

Розрахунок потреби у фахівцях технічно здійснюється як на галузевому, так і на територіальному рівнях. Для визначення потреби в кваліфікованих кадрах прийнято використовувати, в основному, такі методи: нормативний (нормативів насиченості, пाтатний, штатно-номенклатурний, штатно-нормативний), балансовий, економіко-математичне моделювання, експертне оцінювання, порівняння. Існують, проте, й інші підходи.

Не розглядаючи детально описані в літературі вищезазначені групи методів визначення КРОЗ, підкреслимо, що загальними недоліками зазначених методів $\epsilon$ складність формалізації потреби в ресурсах і необхідність певних, часто суттєвих спрощень численних важливих факторів, що впливають на процес формування ресурсів кваліфікованих кадрів.

Саме тому найчастіше в охороні здоров'я застосовують методи експертних оцінок (у тому числі й для встановлення питомої ваги фахівців у кожній конкретній групі спеціальностей), а також методи порівняння (на основі аналізу розвитку явищ і процесів у високорозвиненій системі здійснюється проектування для менш розвиненої системи). Наприклад, при 
виборі стратегії підготовки кадрів конкретного регіону за основу інколи береться район із найвищим по країні (чи оптимальним на думку експертів) рівнем насиченості фахівцями.

Розглянемо формалізовані труднощі розрахунку КРОЗ. За даними численних дослідників може бути інтегровано в процес аналізу понад 50 факторів.

Для розуміння проблеми зупинимося лише на деяких їх групах:

1. Для початку необхідні дані щодо трендів демографічних, епідеміологічних, географічних і соціально-культурних характеристик населення.

2. Важливим $\epsilon$ аналіз динаміки соціальних переваг окремих контингентів населення, технологічних i організаційних змін надання медичної допомоги населенню (наприклад, зміна акцентів медичної допомоги в сторону первинної медико-санітарної допомоги). В старіючого населення європейських країн складається така структура потреб, що вимагає зміщення акцентів у бік послуг, пов' язаних iз веденням хронічних станів, наданням соціальної допомоги в більшому обсязі та реагуванням на потреби, що виникають у кінці життя. Поява нових інфекційних захворювань і повернення «старих», таких як туберкульоз, створює нові потреби в доповнення до вже існуючих. Зазначене вимагає коригування в складі КРОЗ. Крім того, попит на послуги також буде змінюватися під дією таких факторів, як зростаючі очікування споживачів, технічні нововведення (лікарські засоби та вироби медичного призначення).

3. Ступінь розвитку інформаційних і комунікаційних технологій, що полегшують отримання високотехнологічної допомоги, телемедичних послуг тощо.

4. Ступінь міграції населення та міграції фахівців. Очевидно, що немає сенсу навчати достатню кількість лікарів (провізорів) або медсестер, а потім реєструвати їх виїзд до іншиих країн через відсутність попиту на вітчизняному ринку праці, або через те, що умови роботи недостатньо привабливі. Задоволення потреб у КРОЗ передбачає щось більше, ніж просто підготовку більшої кількості працівників: зростання кадрового потенціалу може бути досягнуто за рахунок підвищення мотивації до праці, кваліфікації, змінення професійно-кваліфікаційної структури кадрів і підвищення продуктивності.

5. Існує велика група методологічних труднощів. Так, нинішній стан інформаційних баз даних не дозволяє отримати адекватну відповідь про існуючий кадровий потенціал, оскільки не існує повних даних про приватний сектор, формальний та неформальний сектори в сфері соціального догляду, відомчу та «альтернативну медицину».

6. Відзначимо крайній розкид в оцінці ролі та ефективності різних форм підготовки фахівців - інтернатури, клінічної ординатури, резидентури, спеціалізації.

Тим не менш, є змога сформулювати можливі рішення проблеми, як це було зроблено Всесвітньою організацією охорони здоров' я $[4,6,7,8]$. Розглянемо іх детальніше.

Перше з них визначає співвідночения числа праиівників $і$ чисельності населення. Далі на цій основі шляхом їх порівняння для різних країн (або різних регіонів) формулюються певні висновки. Проте складність інтерпретації, неможливість повного обліку різних категорій лікарів і т.д. роблять практичне застосування підходу реальним лише в плані пілотноїоцінки ситуації.

Також описано підхід, заснований на показниках користування медичними послугами чи попиту наних, що може бути корисним для оцінки майбутніх потреб у медичному обслуговуванні в рамках вирішення окремих соціальних завдань, наприклад боротьби з малюковою чи материнською смертністю, старінням населення. При цьому можна привернути увагу керівників вищої ланки на додаткові витрати, які потрібно буде оплачувати, якщо пропозиція працівників охорони здоров' я зростатиме такими ж темпами, як і попит на них. Проте попит на послуги охорони здоров'я вкрай чутливий до професійних, економічних і соціально-культурних чинників. Подібна асиметричність інформації на користь постачальників може призвести до певної форми стимулювання (добровільного або недобровільного) попиту на такі послуги, як діагностичні процедури, перебування в стаціонарі та призначення ліків, а також обсягів та форм підготовки спеціалістів, що є неприйнятним.

Підхід на основі иільових показників обслуговування також відносно простий і привабливий, оскільки населення легко розуміє і сприймає цільові показники. 3 іншого боку, він має ті ж недоліки, що й підхід, заснований на співвідношенні між числом працівників та чисельністю населення, коли передбачається, що потреби скрізь однакові, а всі постачальники послуг еквівалентні.

Підхід, заснований на потребах у медичній доnомозі та послугах, мабуть, найбільш професійний. Потреби в медичній допомозі, які відповідають розривам між спостережуваним і бажаним станом здоров'я, що виражаються в кількісних показниках (захворюваність і поширеність, стандартизовані показники смертності), представляють основу для 
розрахунку потреб у послугах. Вони являють собою розрив між наявними послугами та послугами, що необхідні для задоволення потреби в здоров'ї. 3 потреб у послугах, у свою чергу, виводяться потреби в ресурсах, зокрема, в кадрових ресурсах охорони здоров'я. Зазначений підхід може бути найприйнятнішим, але його водночас найскладніше застосовувати на практиці. По-перше, дуже недосконалими є відомості про потреби в медичній допомозі на різних рівнях і різного профілю. По-друге, визначення понять “здоров'я" та "потреба в допомозі" є соціальними, малоформалізованими конщепціями, що можуть різнитися залежно від віку, статі, освіти, економічного становища, відстані до надавача медичних послуг тощо. Найголовніше, в цьому підході відсутні кількісні характеристики.

Виходячи з аналізу даних літератури, що свідчить про відсутність переконливих методів розрахунку КРО3, нами запропоновано ще один підхід, заснова-

\section{Література}

1. Dussault G. Оценка будуших потребностей в кадровых pecyрсах здравоохранения / G. Dussault, J. Buchan [et al.].Ла-Юльп : ВО3, 2010. - 54 с. - Режим доступу: http:// www.euro.who.int/_data/assets/pdf_file/0018/133038/ e94295R.pdf.

2. Birch S. Human resources planning and the production of health: a needs-based analytical framework. Canadian Public Policy / S. Birch et al. //Analyse de Politiques. - 2007. - № 33 (Suppl):S1-S16.

3. Claes A [et al.] Planningsmodellen beroepsbeoefenaars in de gezondheidszorg Perceel 3: Uitvoeren enquetes Beroepsgroep Verpleegkundigen Eindrapport [Planning models for health care professions. Parcel 3: the realisation of surveys in health care professions - nurses. Final report]. Brussels, FOD Volksgezondheid, Veiligheid van de Voedselketen en Leefmilieu, Directoraat-generaal Basisgezondheidszorg en Crisisbeheer, Dienst planning gezondheidsberoepen [Federal Public Service (FPS) Health, Food Chain Safety and Environment, Directorate-General Primary Health Care and Crisis Management, Service for the Planning of Health Professions], 2010. - Режим доступу: www.health.fgov.be, accessed 27 July 2010. ний на показниках якості надання медичної допомоги (ЯМД). Застосовуються показники, що належать до так званого індустріального підходу. Проте для оперативного оцінювання потреби в кадрах використовуються прості показники, наприклад, частота лікарських помилок, рівень незадоволеності пацієнтів, показники регіональної неоднорідності показників ЯМД. Особливістю підходу є застосування тренду в якості основних характеристик медичної допомоги.

Висновки. 1. Дотепер відсутній єдиний, прийнятий більшістю країн світу підхід до розрахунку КРОЗ.

2. Відсутне порозуміння щодо найефективнішої форми підготовки спеціалістів.

3. Основоположною проблемою для вирішення повинна стати уніфікована система підготовки фахівців на післядипломному етапі за різними формами (інтернатура, клінічна ординатура, резидентура, спеціалізація), структурою та обсягами.

4. Доклад о состоянии здравоохранения в мире 2006 г. Совместная работа на благо здоровья / Всемирная организация здравоохранения. - Женева, Всемирная организация здравоохранения, 2006. -22 c.

5. Hornby P. Exploring the use of the World Health Organization Human Resources for Health Projection Model. Presented at the HRH Workforce Planning Model Workshop. Washington, DC, 13-14 December 2007.

6. WHO. Models and tools for health workforce planning and projections. Geneva, World Health Organization, Department of Human Resources for Health, Health Information and Governance, 2010 (http:/whqlibdoc.who.int/ publications/ 2010/9789241599016 eng.pdf, accessed 21 July 2010).

7. Health manpower planning: principles, methods, issues / T. Hall,A. Mejia [et al.] - Geneva: World Health Organization, 1978.

8. Green A. An introduction to health planning in developing countries /A. Green. - Oxford: Oxford University Press, 1992. 9. Dreesch N. An approach to estimating human resource requirements to achieve the Millennium Development Goals / N. Dreesch // Health Policy and Planning. - 2005. - Vol. 20 (5). -P. 267-276. 